4

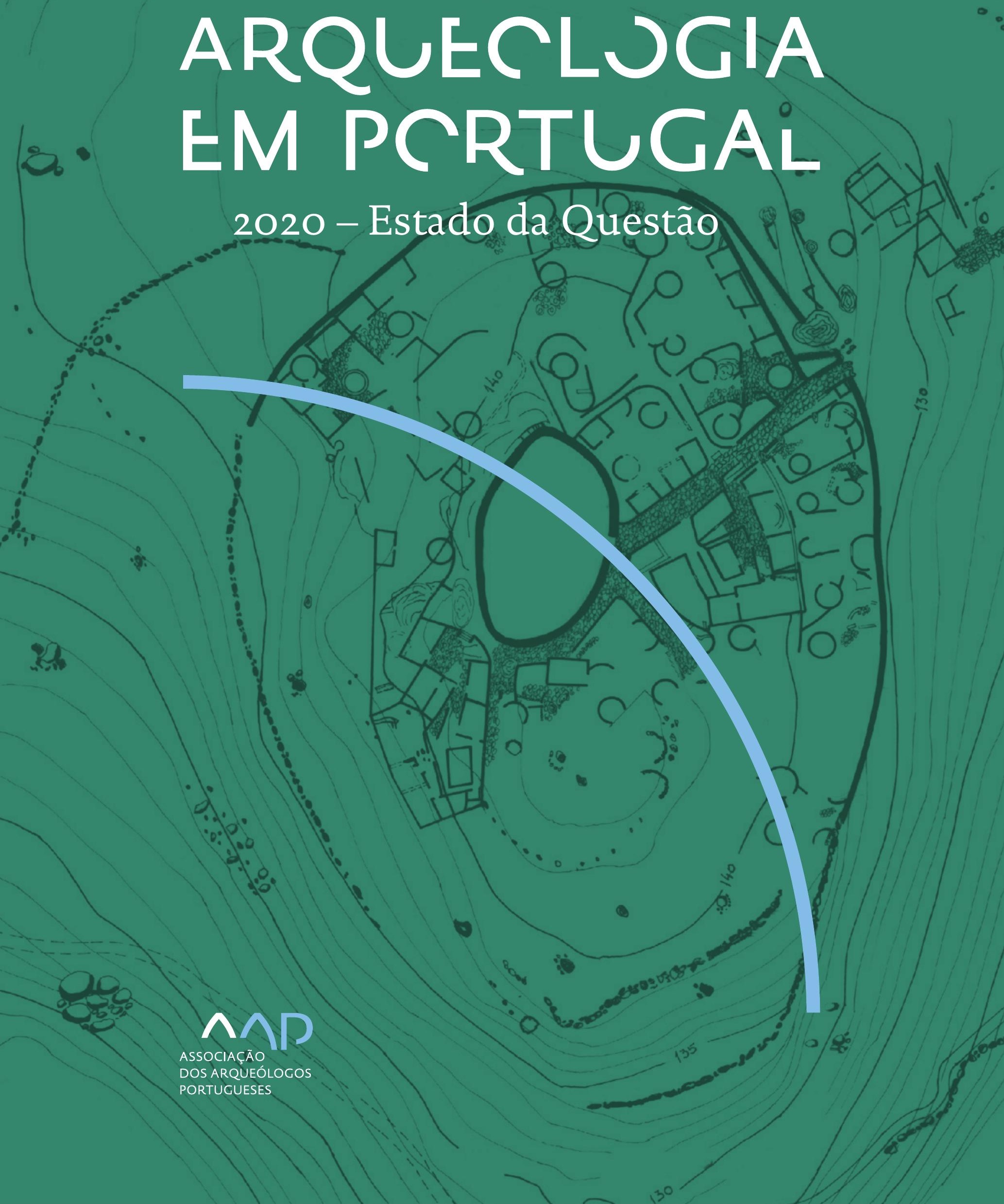


Coordenação editorial: José Morais Arnaud, César Neves e Andrea Martins Design gráfico: Flatland Design

AAP - ISBN: 978-972-9451-89-8

CITCEM - ISBN: 978-989-8970-25-1

Associação dos Arqueólogos Portugueses e CITCEM

Lisboa, 2020

O conteúdo dos artigos é da inteira responsabilidade dos autores. Sendo assim a Associação dos Arqueólogos Portugueses declina qualquer responsabilidade por eventuais equívocos ou questões de ordem ética e legal.

Desenho de capa:

Planta do castro de Monte Mozinho (Museu Municipal de Penafiel).

\section{$\hat{\wedge} \mathrm{P}$}

DOS ARQUEÓLOGOS PORTUGUESES

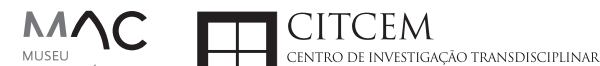
MUSEU
ARQUELLÓGICO
DO CARMO
U.PORTO

FLUP FACULDADE DE LETRAS
UNIVERSIDADE DO PORTO

Apoio

EC para a Ciência 


\section{Índice}

15 Prefácio

José Morais Arnaud

\section{Historiografia e Teoria}

17 Território, comunidade, memória e emoção: a contribuição da história da arqueologia (algumas primeiras e breves reflexões)

Ana Cristina Martins

25 Como descolonizar a arqueologia portuguesa?

Rui Gomes Coelho

41 Arqueologia e Modernidade: uma revisitação pessoal e breve de alguns aspetos da obra homónima de Julian Thomas de 2004

Vítor Oliveira Jorge

57 Dados para a História das Mulheres na Arqueologia portuguesa, dos finais do século XIX aos inícios do século XX: números, nomes e tabelas

Filipa Dimas / Mariana Diniz

73 Retractos da arqueologia portuguesa na imprensa: (in)visibilidades no feminino

Catarina Costeira / Elsa Luís

85 Arqueologia e Arqueólogos no Norte de Portugal Jacinta Bugalhão

101 Vieira Guimarães (1864-1939) e a arqueologia em Tomar: uma abordagem sobre o território e as gentes

João Amendoeira Peixoto / Ana Cristina Martins

115 Os memoráveis? A arqueologia algarvia na imprensa nacional e regional na presente centúria (2001-2019): características, visões do(s) passado(s) e a arqueologia

enquanto marca

Frederico Agosto / João Silva

129 A Evolução da Arqueologia Urbana e a Valorização Patrimonial no Barlavento Algarvio: Os casos de Portimão e Silves

Artur Mateus / Diogo Varandas / Rafael Boavida

\section{Gestão, Valorização e Salvaguarda do Património}

145 O Caderno Reivindicativo e as condições de trabalho em Arqueologia Miguel Rocha / Liliana Matias Carvalho / Regis Barbosa / Mauro Correia / Sara Simões / Jacinta Bugalhão / Sara Brito / Liliana Veríssimo Carvalho / Richard Peace / Pedro Peça / Cézer Santos

155 Os Estudos de Impacte Patrimonial como elemento para uma estratégia sustentável de minimização de impactes no âmbito de reconversões agrícolas Tiago do Pereiro

165 Salvaguarda de Património arqueológico em operações florestais: gestão e sensibilização Filipa Bragança / Gertrudes Zambujo / Sandra Lourenço / Belém Paiva / Carlos Banha / Frederico Tatá Regala / Helena Moura / Jacinta Bugalhão / João Marques / José Correia / Pedro Faria / Samuel Melro

179 Os valores do Património: uma investigação sobre os Sítios Pré-históricos de Arte Rupestre do Vale do Rio Côa e de Siega Verde José Paulo Francisco 
189 Conjugando recursos arqueológicos e naturais para potenciar as visitas ao Geoparque Litoral de Viana do Castelo (Noroeste de Portugal)

Hugo A. Sampaio / Ana M.S. Bettencourt / Susana Marinho / Ricardo Carvalhido

203 Áreas de Potencial Arqueológico na Região do Médio Tejo: Modelo Espacial Preditivo Rita Ferreira Anastácio / Ana Filipa Martins / Luiz Oosterbeek

223 Património Arqueológico e Gestão Territorial: O contributo da Arqueologia para a revisão do PDM de Avis

Ana Cristina Ribeiro

237 A coleção arqueológica do extinto Museu Municipal do Porto - Origens, Percursos e Estudos

Sónia Couto

251 Valpaços - uma nova carta arqueológica

Pedro Pereira / Maria de Fátima Casares Machado

263 Arqueologia na Cidade de Peniche

Adriano Constantino / Luís Rendeiro

273 Arqueologia Urbana: a cidade de Lagos como caso de Estudo Cátia Neto

285 Estratégias de promoção do património cultural subaquático nos Açores. O caso da ilha do Faial

José Luís Neto / José Bettencourt / Luís Borges / Pedro Parreira

297 Carta Arqueológica da Cidade Velha: Uma primeira abordagem

Jaylson Monteiro / Nireide Tavares / Sara da Veiga / Claudino Ramos / Edson Brito /

Carlos Carvalho / Francisco Moreira / Adalberto Tavares

311 Antropologia Virtual: novas metodologias para a análise morfológica e funcional Ricardo Miguel Godinho / Célia Gonçalves

\section{Didáctica da Arqueologia}

327 Como os projetos de Arqueologia podem contribuir para uma comunidade culturalmente mais consciente Alexandra Figueiredo / Claúdio Monteiro / Adolfo Silveira / Ricardo Lopes

337 Educação Patrimonial - Um cidadão esclarecido é um cidadão ativo! Ana Paula Almeida

351 A aproximação da Arqueologia à sala de aula: um caso de estudo no $3^{\circ}$ ciclo do Ensino Básico Luís Serrão Gil

363 Arqueologia 3.o - Pensar e comunicar a Arqueologia para um futuro sustentável Mónica Rolo

377 “Conversa de Arqueólogos" - Divulgar a Arqueologia em tempos de Pandemia Diogo Teixeira Dias

389 Escola Profissional de Arqueologia: desafios e oportunidades Susana Nunes / Dulcineia Pinto / Júlia Silva / Ana Mascarenhas

399 Os Museus de Arqueologia e os Jovens: a oferta educativa para o público adolescente Beatriz Correia Barata / Leonor Medeiros

411 O museu universitário como mediador entre a ciência e a sociedade: o exemplo da secção de arqueologia no Museu de História Natural e da Ciência da Universidade do Porto (MHNC-UP)

Rita Gaspar 
421 Museu de Lanifícios: Real Fábrica de Panos. Atividades no âmbito da Arqueologia Beatriz Correia Barata / Rita Salvado

427 Arqueologia Pública e o caso da localidade da Mata (Torres Novas) Cláudia Manso / Ana Rita Ferreira / Cristiana Ferreira / Vanessa Cardoso Antunes

431 Do sítio arqueológico ao museu: um percurso (também) didático Lídia Fernandes

447 Estão todos convidados para a Festa! E para dançar também... O projecto do Serviço Educativo do Museu Arqueológico do Carmo na $5^{\underline{a}}$ Edição da Festa da Arqueologia Rita Pires dos Santos

459 O “Clã de Carenque”, um projeto didático de arqueologia Eduardo Gonzalez Rocha

469 Mediação cultural: peixe que puxa carroça nas Ruínas Romanas de Troia Inês Vaz Pinto / Ana Patrícia Magalhães / Patrícia Brum / Filipa Santos

481 Didática Arqueológica, experiências do Projeto Mértola Vila Museu Maria de Fátima Palma / Clara Rodrigues / Susana Gómez / Lígia Rafael

\section{Arte Rupestre}

497 Os inventários de arte rupestre em Portugal Mila Simões de Abreu

513 O projeto FIRST-ART - conservação, documentação e gestão das primeiras manifestações de arte rupestre no Sudoeste da Península Ibérica: as grutas do Escoural e Maltravieso Sara Garcês / Hipólito Collado / José Julio García Arranz / Luiz Oosterbeek / António Carlos Silva / Pierluigi Rosina / Hugo Gomes / Anabela Borralheiro Pereira / George Nash / Esmeralda Gomes / Nelson Almeida / Carlos Carpetudo

523 Trabalhos de documentação de arte paleolítica realizados no âmbito do projeto PalæoCôa André Tomás Santos / António Fernando Barbosa / Luís Luís / Marcelo Silvestre / Thierry Aubry

537 Imagens fantasmagóricas, silhuetas elusivas: as figuras humanas na arte do Paleolítico Superior da região do Côa Mário Reis

$55^{1}$ Os motivos zoomórficos representados nas placas de tear de Vila Nova de São Pedro (Azambuja, Portugal) Andrea Martins / César Neves / José M. Arnaud / Mariana Diniz

571 Arte Rupestre do Monte de Góios (Lanhelas, Caminha). Síntese dos resultados dos trabalhos efectuados em 2007-2009 Mário Varela Gomes

599 Gravuras rupestres de barquiformes no Monte de S. Romão, Guimarães, Noroeste de Portugal Daniela Cardoso

613 Círculos segmentados gravados na Bacia do Rio Lima (Noroeste de Portugal): contributos para o seu estudo Diogo Marinho / Ana M.S. Bettencourt / Hugo Aluai Sampaio

631 Equídeos gravados no curso inferior do Rio Mouro, Monção (NW Portugal). Análise preliminar Coutinho, L.M. / Bettencourt, A.M.S / Sampaio, Hugo A.S

645 Paletas na Arte Rupestre do Noroeste de Portugal. Inventário preliminar Bruna Sousa Afonso / Ana M. S. Bettencourt / Hugo A. Sampaio 


\section{Pré-História}

661 O projeto Miño/Minho: balanço de quatro anos de trabalhos arqueológicos Sérgio Monteiro-Rodrigues / João Pedro Cunha-Ribeiro / Eduardo Méndez-Quintas / Carlos Ferreira / Pedro Xavier / José Meireles / Alberto Gomes / Manuel Santonja / Alfredo Pérez-González

677 A ocupação paleolítica da margem esquerda do Baixo Minho: a indústria lítica do sítio de Pedreiras 2 (Monção, Portugal) e a sua integração no contexto regional Carlos Ferreira / João Pedro Cunha-Ribeiro / Sérgio Monteiro-Rodrigues / Eduardo Méndez-Quintas / Pedro Xavier / José Meireles / Alberto Gomes / Manuel Santonja / Alfredo Pérez-González

693 O sítio acheulense do Plistocénico médio da Gruta da Aroeira Joan Daura / Montserrat Sanz / Filipa Rodrigues / Pedro Souto / João Zilhão

703 As sociedades neandertais no Barlavento algarvio: modelos preditivos com recurso aos SIG

Daniela Maio

715 A utilização de quartzo durante o Paleolítico Superior no território dos vales dos rios Vouga e Côa

Cristina Gameiro / Thierry Aubry / Bárbara Costa / Sérgio Gomes / Luís Luís / Carmen Manzano / André Tomás Santos

733 Uma perspetiva diacrónica da ocupação do concheiro do Cabeço da Amoreira (Muge, Portugal) a partir da tecnologia lítica Joana Belmiro / João Cascalheira / Célia Gonçalves

745 Novos dados sobre a Pré-história Antiga no concelho de Palmela. A intervenção arqueológica no sítio do Poceirão I

Michelle Teixeira Santos

757 Problemas em torno de Datas Absolutas Pré-Históricas no Norte do Alentejo Jorge de Oliveira

771 Povoamento pré-histórico nas áreas montanhosas do NO de Portugal: o Abrigo 1 de Vale de Cerdeira Pedro Xavier / José Meireles / Carlos Alves

783 Apreciação do povoamento do Neolítico Inicial na Baixa Bacia do Douro. A Lavra I (Serra da Aboboreira) como caso de estudo Maria de Jesus Sanches

797 O Processo de Neolitização na Plataforma do Mondego: os dados do Sector C do Outeiro dos Castelos de Beijós (Carregal do Sal)

João Carlos de Senna-Martinez / José Manuel Quintã Ventura / Andreia Carvalho / Cíntia Maurício

823 Novos trabalhos na Lapa da Bugalheira (Almonda, Torres Novas) Filipa Rodrigues / Pedro Souto / Artur Ferreira / Alexandre Varanda / Luís Gomes / Helena Gomes / João Zilhão

837 A pedra polida e afeiçoada do sítio do Neolítico médio da Moita do Ourives (Benavente, Portugal)

César Neves

857 Casal do Outeiro (Encarnação, Mafra): novos contributos para o conhecimento do povoamento do Neolítico final na Península de Lisboa.

Cátia Delicado / Carlos Maneira e Costa / Marta Miranda / Ana Catarina Sousa

873 Stresse infantil, morbilidade e mortalidade no sítio arqueológico do Neolítico Final/ Calcolítico ( $4^{\circ}$ e $3^{\circ}$ milénio a.C.) do Monte do Carrascal 2 (Ferreira do Alentejo, Beja) Liliana Matias de Carvalho / Sofia N. Wasterlain 
885 Come together: O Conjunto Megalítico das Motas (Monção, Viana do Castelo) e as expressões Campaniformes do Alto Minho Ana Catarina Basílio / Rui Ramos

899 Trabalhos arqueológicos no sítio Calcolítico da Pedreira do Poio Carla Magalhães / João Muralha / Mário Reis / António Batarda Fernandes

913 O sítio arqueológico de Castanheiro do Vento. Da arquitectura do sítio à arquitectura de um território João Muralha Cardoso

925 Estudo zooarqueológico das faunas do Calcolítico final de Vila Nova de São Pedro (Azambuja, Portugal): Campanhas de 2017 e 2018 Cleia Detry / Ana Catarina Francisco / Mariana Diniz / Andrea Martins / César Neves / José Morais Arnaud

943 As faunas depositadas no Museu Arqueológico do Carmo provenientes de Vila Nova de São Pedro (Azambuja): as campanhas de 1937 a 1967 Ana Catarina Francisco / Cleia Detry / César Neves / Andrea Martins / Mariana Diniz / José Morais Arnaud

959 Análise funcional de material lítico em sílex do castro de Vila Nova de S. Pedro (Azambuja, Portugal): uma primeira abordagem Rafael Lima

971 O recinto da Folha do Ouro 1 (Serpa) no contexto dos recintos de fossos calcolíticos alentejanos

António Carlos Valera / Tiago do Pereiro / Pedro Valério / António M. Monge Soares

\section{Proto-História}

987 Produção de sal marinho na Idade do Bronze do noroeste Português. Alguns dados para uma reflexão

Ana M. S. Bettencourt / Sara Luz / Nuno Oliveira / Pedro P. Simões / Maria Isabel C. Alves / Emílio Abad-Vidal

1001 A estátua-menir do Pedrão ou de São Bartolomeu do Mar (Esposende, noroeste de Portugal) no contexto arqueológico da fachada costeira de entre os rios Neiva e Cávado Ana M. S. Bettencourt / Manuel Santos-Estévez / Pedro Pimenta Simões / Luís Gonçalves

1015 O Castro do Muro (Vandoma/Baltar, Paredes) - notas para uma biografia de ocupação da Idade do Bronze à Idade Média

Maria Antónia D. Silva / Ana M. S. Bettencourt / António Manuel S. P. Silva / Natália Félix

1031 Do Bronze Final à Idade Média - continuidades e hiatos na ocupação de Povoados em Oliveira de Azeméis João Tiago Tavares / Adriaan de Man

1041 As faunas do final da Idade do Bronze no Sul de Portugal: leituras desde o Outeiro do Circo (Beja)

Nelson J. Almeida / Íris Dias / Cleia Detry / Eduardo Porfírio / Miguel Serra

1055 A Espada do Monte das Oliveiras (Serpa) - uma arma do Bronze Pleno do Sudoeste Rui M. G. Monge Soares / Pedro Valério / Mariana Nabais / António M. Monge Soares

1065 São Julião da Branca (Albergaria-a-Velha) - Investigação e valorização de um povoado do Bronze Final

António Manuel S. P. Silva / Paulo A. P. Lemos / Sara Almeida e Silva / Edite Martins de Sá

1083 Do castro de S. João ao Mosteiro de Santa Clara: notícia de uma intervenção arqueológica, em Vila do Conde Rui Pinheiro 
1095 O castro de Ovil (Espinho), um quarto de século de investigação - resultados e questões em aberto

Jorge Fernando Salvador / António Manuel S. P. Silva

1111 O Castro de Salreu (Estarreja), um povoado proto-histórico no litoral do Entre Douro e Vouga

Sara Almeida e Silva / António Manuel S. P. Silva / Paulo A. P. Lemos / Edite Martins de Sá

1127 Castro de Nossa Senhora das Necessidades (Sernancelhe): uma primeira análise artefactual Telma Susana O. Ribeiro

${ }_{1141}$ A cividade de Bagunte. O estado atual da investigação Pedro Brochado de Almeida

1153 Zoomorfos na cerâmica da Idade do Ferro no NW Peninsular: inventário, cronologias e significado Nuno Oliveira / Cristina Seoane

1163 Vasos gregos em Portugal: diferentes maneiras de contar a história do intercâmbio cultural na Idade do Ferro

Daniela Ferreira

1175 Os exotica da necrópole da Idade do Ferro do Olival do Senhor dos Mártires (Alcácer do Sal) no seu contexto regional

Francisco B. Gomes

\section{Antiguidade Clássica e Tardia}

1191 O uso de madeira como combustível no sítio da Quinta de Crestelos (Baixo Sabor): da Idade do Ferro à Romanização Filipe Vaz / João Tereso / Sérgio Simões Pereira / José Sastre / Javier Larrazabal Galarza / Susana Cosme / José António Pereira / Israel Espi

1207 Cultivos de Época Romana no Baixo Sabor: continuidade em tempos de mudança? João Pedro Tereso / Sérgio Simões Pereira / Filipe Santos / Luís Seabra / Filipe Vaz

1221 A casa romana na Hispânia: aplicação dos modelos itálicos nas províncias ibéricas Fernanda Magalhães / Diego Machado / Manuela Martins

1235 As pinturas murais romanas da Rua General Sousa Machado, n. ${ }^{5}$ 1, Chaves José Carvalho

1243 Trás do Castelo (Vale de Mir, Pegarinhos, Alijó) - Uma exploração agrícola romana do Douro

Tony Silvino / Pedro Pereira

1255 A sequência de ocupação no quadrante sudeste de Bracara Augusta: as transformações de uma unidade doméstica Lara Fernandes / Manuela Martins

1263 Os Mosaicos com decoração geométrica e geométrico-vegetalista dos sítios arqueológicos da área do Conuentus Bracaraugustanus. Novas abordagens quanto à conservação, restauro, decoração e datação Maria de Fátima Abraços / Licínia Wrench

1277 “Casa Romana” do Castro de São Domingos (Cristelos, Lousada): Escavação, Estudo e Musealização Paulo André de P. Lemos

1291 A arqueobotânica no Castro de Guifões (Matosinhos, Noroeste de Portugal): O primeiro estudo carpológico

Luís Seabra / Andreia Arezes / Catarina Magalhães / José Varela / João Pedro Tereso 
1305 Um Horreum Augustano na Foz do Douro (Monte do Castelo de Gaia, Vila Nova de Gaia) Rui Ramos

1311 Ponderais romanos na Lusitânia: padrões, formas, materiais e contextos de utilização Diego Barrios Rodríguez

1323 Um almofariz centro-itálico na foz do Mondego

Marco Penajoia

1335 Estruturas romanas de Carnide - Lisboa Luísa Batalha / Mário Monteiro / Guilherme Cardoso

1347 O contexto funerário do sector da "necrópole NO" da Rua das Portas de S. Antão (Lisboa): o espaço, os artefactos, os indivíduos e a sua interconectividade na interpretação do passado Sílvia Loja, José Carlos Quaresma, Nelson Cabaço, Marina Lourenço, Sílvia Casimiro, Rodrigo Banha da Silva, Francisca Alves-Cardoso

${ }_{1361}$ Povoamento em época Romana na Amadora - resultados de um projeto pluridisciplinar Gisela Encarnação / Vanessa Dias

1371 A Arquitectura Residencial em Mirobriga (Santiago do Cacém): contributo a partir de um estudo de caso Filipe Sousa / Catarina Felício

${ }_{1385}$ O fim do ciclo. Saneamento e gestão de resíduos nos edifícios termais de Mirobriga (Santiago do Cacém)

Catarina Felício / Filipe Sousa

1399 Balsa, Topografia e Urbanismo de uma Cidade Portuária Vítor Silva Dias / João Pedro Bernardes / Celso Candeias / Cristina Tété Garcia

1413 No Largo das Mouras Velhas em Faro (2017): novas evidências da necrópole norte de Ossonoba e da sua ocupação medieval Ricardo Costeira da Silva / Paulo Botelho / Fernando Santos / Liliana Nunes

1429 Instrumentos de pesca recuperados numa fábrica de salga em Ossonoba (Faro) Inês Rasteiro / Ricardo Costeira da Silva / Paulo Botelho

1439 A Necrópole Romana do Eirô, Duas Igrejas (Penafiel): intervenção arqueológica de 2016 Laura Sousa / Teresa Soeiro

1457 Ritual, descarte ou afetividade? A presença de Canis lupus familiaris na Necrópole Noroeste de Olisipo (Lisboa)

Beatriz Calapez Santos / Sofia Simões Pereira / Rodrigo Banha da Silva / Sílvia Casimiro / Cleia Detry / Francisca Alves Cardoso

1467 Dinâmicas económicas em Bracara na Antiguidade Tardia Diego Machado / Manuela Martins / Fernanda Magalhães / Natália Botica

1479 Cerâmicas e Vidros da Antiguidade Tardia do Edifício sob a Igreja do Bom Jesus (Vila Nova de Gaia) Joaquim Filipe Ramos

1493 Novos contributos para a topografia histórica de Mértola no período romano e na Antiguidade Tardia Virgílio Lopes

\section{8. Época Medieval}

1511 Cerâmicas islâmicas no Garb setentrional "português": algumas evidências e incógnitas Constança dos Santos / Helena Catarino / Susana Gómez / Maria José Gonçalves / Isabel Inácio / Gonçalo Lopes / Jacinta Bugalhão / Sandra Cavaco / Jaquelina Covaneiro / Isabel Cristina Fernandes / Ana Sofia Gomes 
1525 Contributo para o conhecimento da cosmética islâmica, em Silves, durante a Idade Média Rosa Varela Gomes

1537 Yábura e o seu território - uma análise histórico-arqueológica de Évora entre os séculos VIII-XII José Rui Santos

1547 A encosta sul do Castelo de Palmela - resultados preliminares da escavação arqueológica Luís Filipe Pereira / Michelle Teixeira Santos

1559 A igreja de São Lourenço (Mouraria, Lisboa): um conjunto de silos e de cerâmica medieval islâmica

Andreia Filipa Moreira Rodrigues

1571 O registo material de movimentações populacionais no Médio Tejo, durante os séculos XII-XIII. Dois casos de "sunken featured buildings", nos concelhos de Cartaxo e Torres Novas Marco Liberato / Helena Santos / Nuno Santos

1585 O nordeste transmontano nos alvores da Idade média. Notas para reflexão Ana Maria da Costa Oliveira

1601 Sepulturas escavadas na rocha do Norte de Portugal e do Vale do Douro: primeiros resultados do Projecto SER-NPVD

Mário Jorge Barroca / César Guedes / Andreia Arezes / Ana Maria Oliveira

1619 "Portucalem Castrum Novum" entre o Mediterrâneo e o Atlântico: o estudo dos materiais cerâmicos alto-medievais do arqueossítio da rua de D. Hugo, nํ. 5 (Porto) João Luís Veloso

1627 A Alta Idade Média na fronteira de Lafões: notas preliminares sobre a Arqueologia no Concelho de Vouzela

Manuel Luís Real / Catarina Tente

1641 Um conjunto cerâmico medieval fora de portas: um breve testemunho aveirense Susana Temudo

${ }_{1651}$ Os Lóios do Porto: uma perspetiva integrada no panorama funerário da Baixa Idade Média à Época Moderna em meios urbanos em Portugal

Ana Lema Seabra

1659 O Caminho Português Interior de Santiago como eixo viário na Idade Média Pedro Azevedo

1665 Morfologia Urbana: Um exercício em torno do Castelo de Ourém André Donas-Botto / Jaqueline Pereira

1677 Intervenção arqueológica na Rua Marquês de Pombal/Largo do Espírito Santo (Bucelas, Loures)

Florbela Estêvão / Nathalie Antunes-Ferreira / Dário Ramos Neves / Inês Lisboa

1691 O Cemitério Medieval do Poço do Borratém e a espacialidade funerária na cidade de Lisboa Inês Belém / Vanessa Filipe / Vasco Noronha Vieira / Sónia Ferro / Rodrigo Banha da Silva

1705 Um Espaço Funerário Conventual do séc. XV em Lisboa: o caso do Convento de São Domingos da Cidade Sérgio Pedroso / Sílvia Casimiro / Rodrigo Banha da Silva / Francisca Alves Cardoso

\section{9. Época Moderna e Contemporânea}

1721 Arqueologia Moderna em Portugal: algumas reflexões críticas em torno da quantificação de conjuntos cerâmicos e suas inferências históricas e antropológicas Rodrigo Banha da Silva / André Bargão / Sara da Cruz Ferreira

1733 Faianças de dois contextos entre os finais do século XVI e XVIII do Palácio dos Condes de Penafiel, Lisboa

Martim Lopes / Tomás Mesquita 
1747 Um perfil de consumo do século XVIII na foz do Tejo: O caso do Mercado da Ribeira, Lisboa Sara da Cruz Ferreira / Rodrigo Banha da Silva / André Bargão

1761 Os Cachimbos dos Séculos XVII e XVIII do Palácio Mesquitela e Convento dos Inglesinhos (Lisboa)

Inês Simão / Marina Pinto / João Pimenta / Sara da Cruz Ferreira / André Bargão / Rodrigo Banha da Silva

1775 "Tomar os fumos da erua que chamão em Portugal erua sancta». Estudo de Cachimbos provenientes da Rua do Terreiro do Trigo, Lisboa

Miguel Martins de Sousa / José Pedro Henriques / Vanessa Galiza Filipe

1787 Cachimbos de Barro Caulínitico da Sé da Cidade Velha (República de Cabo Verde)

Rodrigo Banha da Silva / João Pimenta / Clementino Amaro

1801 Algumas considerações sobre espólio não cerâmico recuperado no Largo de Jesus (Lisboa) Carlos Boavida

1815 Adereços de vidro, dos séculos XVI-XVIII, procedentes do antigo Convento de Santana de Lisboa (anéis, braceletes e contas)

Joana Gonçalves / Rosa Varela Gomes / Mário Varela Gomes

1837 Da ostentação, luxo e poder à simplicidade do uso quotidiano: arqueologia e simbologia de joias e adornos da Idade Moderna Portuguesa Jéssica Iglésias

1849 Os amuletos em Portugal - dos objetos às superstições: o coral vermelho Alexandra Vieira

1865 Cerâmicas de Vila Franca de Xira nos séculos XV e XVI Eva Pires

1879 «Não passa por teu o que me pertence». Marcas de individualização associadas a faianças do Convento de Nossa Senhora de Aracoeli, Alcácer do Sal Catarina Parreira / Íris Fragoso / Miguel Martins de Sousa

1891 Cerâmica de Leiria: alguns focos de produção

Jaqueline Pereira / André Donas-Botto

1901 Os Fornos na Rua da Biquinha, em Óbidos Hugo Silva / Filipe Oliveira

1909 A casa de Pêro Fernandes, contador dos contos de D. Manuel I: o sítio arqueológico da Silha do Alferes, Seixal (século XVI) Mariana Nunes Ferreira

1921 O Alto da Vigia (Sintra) e a vigilância e defesa da costa Alexandre Gonçalves / Sandra Santos

1937 O contexto da torre sineira da Igreja de Santa Maria de Loures Paulo Calaveira / Martim Lopes

1949 A Necrópole do Hospital Militar do Castelo de São Jorge e as práticas funerárias na Lisboa de Época Moderna Susana Henriques / Liliana Matias de Carvalho / Ana Amarante / Sofia N. Wasterlain

1963 SAND - Sarilhos Grandes Entre dois Mundos: o adro da Igreja e a Paleobiologia dos ossos humanos recuperados

Paula Alves Pereira / Roger Lee Jesus / Bruno M. Magalhães

1975 Expansão urbana da vila de Cascais no século XVII e XVIII: a intervenção arqueológica na Rua da Vitória no 15 a 17

Tiago Pereira / Vanessa Filipe

1987 Novos dados para o conhecimento do Urbanismo de Faro em época Moderna Ana Rosa 
1995 Um exemplo de Arqueologia Urbana em Alcoutim: o Antigo Edifício dos CTT Marco Fernandes / Marta Dias / Alexandra Gradim / Virgílio Lopes / Susana Gómez Martínez

2007 Palácio dos Ferrazes (Rua das Flores/Rua da Vitória, Porto): a cocheira de Domingos Oliveira Maia

Francisco Raimundo

2021 As muitas vidas de um edifício urbano: História, Arqueologia e Antropologia no antigo Recreatório Paroquial de Penafiel Helena Bernardo / Jorge Sampaio / Marta Borges

2035 O convento de Nossa Senhora da Esperança de Ponta Delgada: o contributo da arqueologia para o conhecimento de um monumento identitário João Gonçalves Araújo / N’Zinga Oliveira

2047 Arqueologia na ilha do Corvo... em busca da capela de Nossa Senhora do Rosário Tânia Manuel Casimiro / José Luís Neto / Luís Borges / Pedro Parreira

2059 Perdidos à vista da Costa. Trabalhos arqueológicos subaquáticos na Barra do Tejo Jorge Freire / José Bettencourt / Augusto Salgado

2071 Arqueologia marítima em Cabo Verde: enquadramento e primeiros resultados do projecto CONCHA

José Bettencourt / Adilson Dias / Carlos Lima / Christelle Chouzenoux / Cristóvão Fonseca / Dúnia Pereira / Gonçalo Lopes / Inês Coelho / Jaylson Monteiro / José Lima / Maria Eugénia Alves / Patrícia Carvalho / Tiago Silva

2085 Trabalhos arqueológicos na Cidade Velha (Ribeira Grande de Santiago, Cabo Verde): reflexões sobre um projecto de investigação e divulgação patrimonial André Teixeira / Jaylson Monteiro / Mariana Mateus / Nireide Tavares / Cristovão Fonseca / Gonçalo C. Lopes / Joana Bento Torres / Dúnia Pereira / André Bargão / Aurélie Mayer / Bruno Zélie / Carlos Lima / Christelle Chouzenoux / Inês Henriques / Inês Pinto Coelho / José Lima / Patrícia Carvalho / Tiago Silva

2103 A antiga fortificação de Quelba / Khor Kalba (E.A.U.). Resultados de quatro campanhas de escavações, problemáticas e perspectivas futuras Rui Carita / Rosa Varela Gomes / Mário Varela Gomes / Kamyar Kamyad

2123 Colónias para homens novos: arqueologia da colonização agrária fascista no noroeste ibérico Xurxo Ayán Vila / José Mạ . Señorán Martín 


\title{
EXPANSÃO URBANA DA VILA DE CASCAIS NO SÉCULO XVII E XVIII: A INTERVENÇÃO ARQUEOLÓGICA NA RUA DA VITÓRIA $\mathrm{N}^{\circ} 15$ A 17
}

Tiago Pereira ${ }^{1}$, Vanessa Filipe ${ }^{2}$

\begin{abstract}
RESUMO
Os trabalhos arqueológicos realizados na Rua da Vitória nํ15 a 17 em Cascais, no âmbito de um projeto de reabilitação urbana, tiveram como objectivo a escavação integral do subsolo no interior do edifício. A intervenção permitiu caracterizar o edifício original implantado neste local entre os finais do século XVII início do século XVIII. Os dados aqui apresentados apontam para um espaço urbano que é precedido por uma pequena área de exploração agrícola, abandonado com o aparecimento de aterros e fossas para despejo de lixo doméstico.

Estamos perante a evolução urbana da vila de Cascais com a expansão para áreas limítrofes pouco urbanizadas e anteriormente utilizadas como lixeiras da vila.

Palavras-chave: Arqueologia Urbana, Idade Moderna, Cultura material, Vila de Cascais.
\end{abstract}

\begin{abstract}
The archaeological intervention at Rua da Vitória 15-17, Cascais, was motivated by an urban rehabilitation project for a buldind located nearby the center of the village.

The original bulding foundation date from late $17^{\text {th }}$ century and $18^{\text {th }}$ century, above a series of deposits containing ceramics, fauna, glass and metals as a result of landfill of domestic waste. Between these deposits we registered several small pits used as household waste disposal. The previous occupation in this area corresponds to a minor agricultural production from $15^{\text {th }}$ or $16^{\text {th }}$ century probably a small vineyard field.

We report were evidence of the urban expansion of ancient village of Cascais occurred since $16^{\text {th }}$ century, and the development of urban area to open areas of landfill.
\end{abstract}

Keywords: Urban archaeology, Modern Age, Material Culture, Village of Cascais.

\section{INTRODUÇÃO}

O núcleo histórico da vila de Cascais tem sido alvo de estudo de forma sistemática desde os anos 80 do século XX. Nas últimas décadas as intervenções no subsolo do espaço urbano da vila, motivadas pelos diversos empreendimentos de reabilitação urbana e de infraestruturas, têm revelado potencial arqueológico para o delinear da evolução urbanística de Cascais.

A reabilitação do edifício nํㅗ 15 a 17 da Rua da Vitória em Cascais (Figura 1), localizado em diversas zonas de proteção patrimonial, conduziu à prossecução da intervenção arqueológica entre Março e Maio de 2018. Foi realizada a escavação integral do subsolo no interior do edifício condicionada pela cota de afetação de obra, permitindo aferir algumas ocorrências patrimoniais, identificando-se diversas estruturas e espólio arqueológico nos diversos compartimentos do edifício.

Este trabalho é o resultado da análise preliminar dos dados da intervenção realizada em 2018, a importân-

1. Arqueólogo COTA 8o 86 / Instituto de Estudos Medievais; tiagopereira@cota8o86.pt

2. Arqueóloga COTA 8086 / Instituto de Arqueologia e Paleociências; vanessafilipe@cota8o86.pt 
cia dos contextos analisados e cronologias estabelecidas da urbanização desta área no enquadramento do contexto urbanístico da antiga vila de Cascais.

\section{A INTERVENÇÃO ARQUEOLÓGICA}

Os trabalhos arqueológicos levados a cabo no edifício ocorreram após as demolições efectuadas do interior do edifício, com o levantamento dos diferentes pavimentos contemporâneos do edifício. Após a remoção destes pisos a área intervencionada foi condicionada a seis compartimentos definidos pelos muros da estrutura interna do edifício (Figura 2). Essa estrutura interna é composta por elementos estruturais relacionada com a construção primitiva do edifício.

A espinha dorsal do edifício corresponde a uma estrutura de alvenaria em pedra e argamassa com cerca de o,8 $\mathrm{m}$ de largura, no sentido este-oeste, subsidiado por dois muros perpendiculares e duas estruturas muradas de diferentes características, apresentando ainda vestígios de uma antiga soleira afetada pelas sucessivas alterações estruturais no edifício.

Este conjunto estrutural forma uma série de compartimentos na área intervencionada, com diferentes dimensões, compreendendo três a norte e três a sul. Em quatro dos compartimentos (Compartimento 1, 2, 3 e 5) foram identificados diferentes ramais de saneamento do edifício, assim como as estruturas a eles associados - trata-se de muros elaborados com pedra de pequena e média dimensão em fiadas relativamente regulares com ligante de argamassa amarelada e pouco compacta, sustentam tubos de manilha em grês encontrando-se praticamente em toda a área intervencionada. No interior de um destes compartimentos, a sul do edifício, identificou-se um tanque ou fossa desactivado recentemente encontrando-se preenchido no seu interior com entulho de obra. Estas estruturas assentam praticamente em terreno estéril no lado norte do edifício, e em determinadas zonas directamente na rocha.

$\mathrm{Na}$ área do compartimento 6, após a escavação de um nível de entulho sob os pavimentos, identificou-se uma estruturação composta pelo reaproveitamento de lajes de calcário com sulco para encaixe de barrotes ou postes de madeira, assentes em argamassa pouco compacta, com inclusão de soleira de grande dimensão junto à parede sul do edifício. Esta estrutura parece corresponder aos vestígios de uma antiga parede em tabique no interior do edifício, formando um corredor e provavelmente adossado ao muro interior do edifício (Figura 3). O tabique assentava ainda num depósito de aterro para nivelamento do local. No compartimento junto à fachada do edifício, com acesso pela porta $\mathrm{n}^{\circ}{ }^{17}$, foi ainda possível observar vestígios de uma calçada interior de acesso à casa.

A implantação do edifício afectou alguns níveis de aterro, registando-se estratigraficamente níveis de fossas detríticas, de pequena dimensão, entre os aterros identificados na área intervencionada sobretudo nos compartimentos 4, 5 e 6 (Figura 4). No compartimento 4 uma das fossas destaca-se pelo material arqueológico exumado (Figura 5), com a recolha de quatro peças de cerâmica praticamente completas, incluindo um recipiente de importação do norte da Europa.

Entre as estruturas negativas registadas estão ainda associadas um conjunto de buracos de poste de pequena e média dimensão nos diferentes níveis de aterro, alguns deles corresponderão ao momento de construção do edifício.

O nível de ocupação mais antigo identificado durante a intervenção caracteriza-se por um conjunto de buracos sub-rectangulares e alongados, com cerca de $10 \mathrm{~cm}$ de profundidade, associado a pés de vinha, alguns sub-circulares e um sub-ovalado com profundidades entre os $15 \mathrm{e}$ os $30 \mathrm{~cm}$ e pequenos buracos de poste, escavados num depósito quase estéril e bastante argiloso, circunscritos ao compartimento 4 e 6 (Figura 6 e 7 ).

Durante a escavação do depósito onde se inserem foi identificada ainda uma panela depositada in situ praticamente completa (Figura 8). Este depósito sobrepõe o coluvião composto por sedimento siltoso de coloração avermelhada muito compacto que corresponde ao substrato geológico observado em quase toda a área de escavação, excepto nos compartimentos junto à fachada do edifício (compartimentos 5 e 6) onde se atingiu a cota de obra antes do substrato geológico, e no local onde está implantada o tanque/fossa cuja profundidade atinge cotas superiores ao nível dos depósitos estéreis.

Alguns destes depósitos corresponderão a níveis de colovião compostos por sedimento siltoso compacto avermelhado, consolidadas por cimento calcário, ausentes de materiais arqueológicos sobrepondo e/ ou encostando aos lapiás existentes no local. 


\section{EVOLUÇÃO DO ESPAÇO}

Os contextos arqueológicos registados durante a intervenção arqueológica na Rua da Vitória ํㅡำ 15 a 17, permitiram definir diferentes fases de ocupação do espaço em estudo. Porém, a compartimentação $\mathrm{da}$ área intervencionada limitou o enquadramento geral de todas as estruturas identificadas, e uma visão global dos diferentes momentos de utilização do espaço. Estes evidenciam uma progressiva transição de um ambiente rural, ligado a uma produção agrícola possivelmente de carácter familiar, fixando-se posteriormente na malha urbana da vila de Cascais. Os diferentes momentos de ocupação ocorreram entre o século XV/XVI e a atualidade e evidenciam quatro fases distintas.

\subsection{Fase 1 - Século XV/XVI}

Este é o nível de ocupação mais antigo registado durante a intervenção e encontra-se representado sobretudo no compartimento 4 .

Inserem-se neste contexto diversas estruturas negativas relacionadas com uma pequena exploração agrícola em pequena escala: um conjunto de "covachos" alongados, geralmente com orientação NE-SO, que corresponderão aos negativos da implantação de pés de vinha nesta área. São relativamente semelhantes a diversas estruturas negativas desde género, encontrando-se exemplos desde época romana (Pereira, 2017, pp. 99-102).

Os pés de vinha estão associados a pequenos buracos de poste de estruturas de apoio à produção vinícola e a covas ou buracos com maior profundidade, relacionados com a produção de outras culturas como a oliveira - representada por uma cova sub-ovalada com sulco central e cerca de $40 \mathrm{~cm}$ de profundidade identificada no compartimento 4 .

Estas estruturas revelaram escassos materiais arqueológicos assinalando-se apenas o aparecimento de uma bilha parcialmente completa inserida num dos pequenos buracos.

O depósito correspondente ao nível de utilização agrícola revelou igualmente escassos materiais, destacando-se uma panela praticamente completa utilizada possivelmente como vaso de canteiro. Pelas características morfológicas trata-se de um recipiente que se enquadra no século XV.

A exploração agrícola é abandonada durante o século XVI com o aterro de lixo doméstico em toda a área.

\subsection{Fase 2 - Século XVI/XVII}

Durante o século XVI e XVII o local foi aproveitado como lixeira, sucessivos aterros de lixo doméstico com grande quantidade de material cerâmico, de restos alimentares compostos sobretudo por fauna ictiológica, mamalógica e malacológica, e provavelmente de terras sobrantes.

Em pleno século XVII são realizadas diversas fossas nos aterros pré-existentes para descarte de lixo doméstico. Neste contexto, no compartimento 4 , uma fossa detrítica com grande quantidade de material cerâmico revelou algumas peças praticamente completas após colagem, assinalando-se um pequeno pote de farmácia (Albarello) proveniente do norte da Europa.

Entre o século XVII e XVIII o espaço de lixeira cessa com a implantação do edifício original, consequência da expansão urbana da vila de Cascais.

\subsection{Fase 3-Século XVII/XVIII}

A edificação de uma habitação ocorrida entre os finais do século XVII ou já no século XVIII encerra a existência de lixeiras nesta área. A sua configuração primitiva corresponde a um muro em alvenaria de pedra e argamassa, no sentido este-oeste, com vestígios de soleira de acesso à casa do $\mathrm{n}^{0} 15$, posteriormente anulada, e dois muros solidários transversais definindo alguns compartimentos e dividindo possivelmente a área em duas habitações distintas, que corresponderão aos atuais no 15 e 17. A base destas estruturas corta os depósitos de aterro precedentes assentando em determinadas zonas na rocha ou no nível agrícola.

A fase de implantação do edifício caracteriza-se ainda pela presença de distintos buracos de poste, nos diversos compartimentos junto às estruturas, que serviram de apoio para estruturas perecíveis de apoio à sua construção, e vestígios de uma calçada que corresponderá a um pequeno pátio interior de acesso à casa $\mathrm{n}^{\circ} 17$ e obliterada pelas alterações posteriores.

\subsection{Fase 4-Século XIX/XX}

Este período caracteriza-se pelas constantes alterações estruturais no edifício entre os séculos XIX e XX. Durante o século XIX regista-se o assentamento de uma estrutura de tabique junto à entrada $\mathrm{n}^{\circ}{ }^{15}$, com reaproveitamento de soleira, e que reconfigura o compartimento definido pelos muros originais do edifício, muito provavelmente contemporâneo da 
construção de um tanque abobadado recentemente entulhado e de função indeterminada junto a um possível saguão existente na zona oeste do edifício. A implantação de diferentes estruturas de saneamento descritas anteriormente afetam algumas das estruturas mais antigas e os níveis de aterro, com sucessivas alterações e fusões de ramais de esgotos presentes no edifício desde o século XIX.

\section{ESPÓLIO ARQUEOLÓGICO}

O espólio exumado durante a intervenção arqueológica enquadra-se na sua grande maioria no século XVII.

Os depósitos de aterro e fossas detríticas forneceram sobretudo cerâmica comum, vidrada, faiança e alguma cerâmica esmaltada, destacando-se a cerâmica utilitária de cozinha e armazenamento. Algumas destas fossas forneceram abundante cerâmica comum e vidrada, mas também cerâmica esmaltada, faiança, metais e vidros (inclusive um anel).

No contexto dos aterros foram recolhidos recipientes quase completos provenientes de uma das fossas detríticas: uma taça e tacho em cerâmica comum inteiros (Figura 9), um cântaro com perfil completo de uma asa, destacando-se um albarello praticamente completo.

Esta peça apresenta uma pasta entre o rosa e o salmão, decorada com linhas horizontais na parte superior e inferior e linhas onduladas entrelaçadas a meio da peça, pintadas a azul cobalto sobre esmalte branco (Figura 10). A característica da pasta e a decoração utilizada indica que se trata provavelmente de uma produção inglesa da segunda metade do século XVII (Orser, 2018, pp. 48-108) em concordância com a cronologia dos aterros.

A escavação do nível agrícola revelou uma panela colocada in situ (Figura 8), com perfuração circular na base da peça, feita intencionalmente após a cozedura, possivelmente utilizada como vaso de canteiro já que não se verificam marcas uso como superfícies queimadas por acção directa do fogo, associada ao depósito de implantação dos pés de vinha e dos buracos de árvore. Apresenta um bordo em aba de secção rectangular com canelura abaixo do bordo, corpo ovóide com duas asas e fundo convexo. Este tipo de cerâmica apresenta cronologias entre os séculos XIV e XVI à semelhança de outras peças recolhidas no núcleo urbano de cascais (Cardoso e Rodrigues, 1991, pp. 573-584).
As faunas predominantes nestes contextos correspondem à fauna ictiológica e malacológica com menor percentagem da fauna mamalógica, em relação ao número mínimo de indivíduos. Estão associadas às lixeiras do século XVI e XVII, através dos sucessivos despejos, e representam alguma das dietas da população residente na vila durante os séculos XVI e XVII que não será abordada em específico nes te trabalho.

Os materiais de cronologias entre o século XIX e XX estão associados às várias construções do edifício ocorridas neste período. Estes depósitos além da cerâmica, continham metais e vidros com cronologias entre os séculos XVII e XIX, e alguns materiais mais antigos (século XVI), resultante dos sucessivos remeximentos de terras efetuados no local.

Em relação aos metais correspondem sobretudo a pregos e cavilhas em ferro com excepção de alguns alfinetes, numismas e um anel bastante deteriorado, identificado nos níveis de aterro de lixo doméstico.

\section{CONCLUSÃO}

A área correspondente à empreitada permitiu um conhecimento mais aprofundado das suas valências arqueológicas e patrimoniais. Esta análise reflete a necessidade de caracterizar o espaço envolvente à empreitada, respeitando a sua antropização ao longo dos tempos bem como a sua valorização patrimonial. A integração do espaço num contexto mais abrangente, atendendo à delimitação urbana em que se insere a obra, apresenta um carácter imperativo no que concerne ao âmbito da salvaguarda e valorização do património.

A informação recolhida durante a intervenção permite-nos afirmar que as origens do edifício remontam aos finais do século XVII e/ou inícios do século XVIII.

A expansão urbana da Vila de Cascais nesta área parece ter ocorrido neste período, corroborada pelos diversos contextos arqueológicos identificados em zonas próximas da Rua da Vitória. A necessidade de construir novos edifícios habitacionais, estimulada por um aumento demográfico da vila de Cascais a partir do século XVI, conduziu à ocupação de anteriores espaços de lixeira integrando novas áreas na malha urbana da vila (Cardoso \& Rodrigues, 1999, p.194).

No caso específico da Rua da Vitória nํ15 a 17, a urbanização é precedida por uma área rural de exploração 
agrícola, com indícios de produção vinícola de cariz familiar. A limitação da área intervencionada não permitiu relacionar qualquer edifício habitacional associado a um espaço de horta para auto consumo. A utilização agrícola deste espaço perdeu a sua importância ou mesmo abandonado surgindo uma zona livre, para a partir do século XVI, se acumularem diversos aterros e fossas resultantes do descarte de lixo doméstico.

Foram ainda detectadas arqueologicamente algumas alterações e anulações ao edificado, ocorridas ao longo de todo o período de ocupação e uso do mesmo. A expansão urbana ocorrida a partir do século XVI da antiga vila de Cascais encontra-se bem caracterizada neste local, com a ocupação de áreas limítrofes e anteriormente livres para a implantação de novos edifícios habitacionais.

\section{BIBLIOGRAFIA}

ANDRADE, Ferreira de, (1964) - Vila de Corte. Oito Séculos de História. Cascais.

CARDOSO, Guilherme (1993) - Carta arqueológica do concelho de Cascais, Cascais: Câmara Municipal de Cascais.

CARDOSO, Guilherme; Rodrigues, Severino (1991) - Alguns tipos de cerâmica dos sécs. XI a XVI encontrados em Cascais. In A cerâmica medieval no mediterrâneo ocidental: actas do IV Congresso Internacional. Mértola: Campo Arqueológico de Mértola; pp. 573-585.

CARDOSO, Guilherme; RODRIGUES, Severino (1999) Tipologia e cronologia de cerâmicas dos séculos XVI, XVII e XIX encontradas em Cascais. In Arqueologia Medieval (6), pp. 193-212.

CARDOSO, Guilherme; RODRIGUES, Severino (2002) Conjunto de peças de cerâmica do século XVII do Convento da Piedade de Cascais. In Actas do $3^{\circ}$ Encontro Nacional de Arqueologia Urbana. Almada: Museu Municipal, pp. 269-288.

CARDOSO, Guilherme; CABRAL, João Pedro (2004) Povoamento e arquitectura popular na freguesia de Cascais. Cascais: Junta de Freguesia de Cascais.

ENCARNAÇÃO, José de, (1973) - Obras na igreja matriz de Cascais. In Jornal da Costa do Sol, Cascais.

HENRIQUES, João Miguel, (2004) - História da freguesia de Cascais (1870-1908): Uma Proposta de estudo. Edições Colibri, Cascais: Câmara Municipal de Cascais.

ORSER, Charles E. (2018) - An archaeology of the English Atlantic world, 160o-170o. Cambridge: Cambridge University Press.

PEREIRA, Pedro Abrunhosa (2017) - O vinho na Lusitânia. CITCEM, Centro de investigação transdisciplinar "Cultura,
Espaço e memória”. Coleção: Teses Universitárias, 8. Porto: Edições Afrontamento.

RODRIGUES, Severino; BOLILA, Catarina; FILIPE, Vanessa; HENRIQUES, José Pedro Henriques; RIBEIRO, Inês Alves; SIMÕES, Sara Teixeira (2012) - As cerâmicas da Idade Moderna da Fortaleza de Nossa Senhora da Luz, Cascais. Velhos e Novos Mundos: Estudos de Arqueologia Moderna. Lisboa. Volume 2, Colecção Arqueoarte nº 1, Centro de História de Além-Mar, Faculdade de Ciências Sociais e Humana, Universidade Nova de Lisboa, pp. 865-876.

SHLASKO, Ellen (1989) - Delftware chronology: A new approach to dating English tin-glazed ceramics. Dissertations, Theses, and Masters Projects. Paper 1539625501. https://dx. doi.org/doi:10.21220/s2-tmdb-do88 


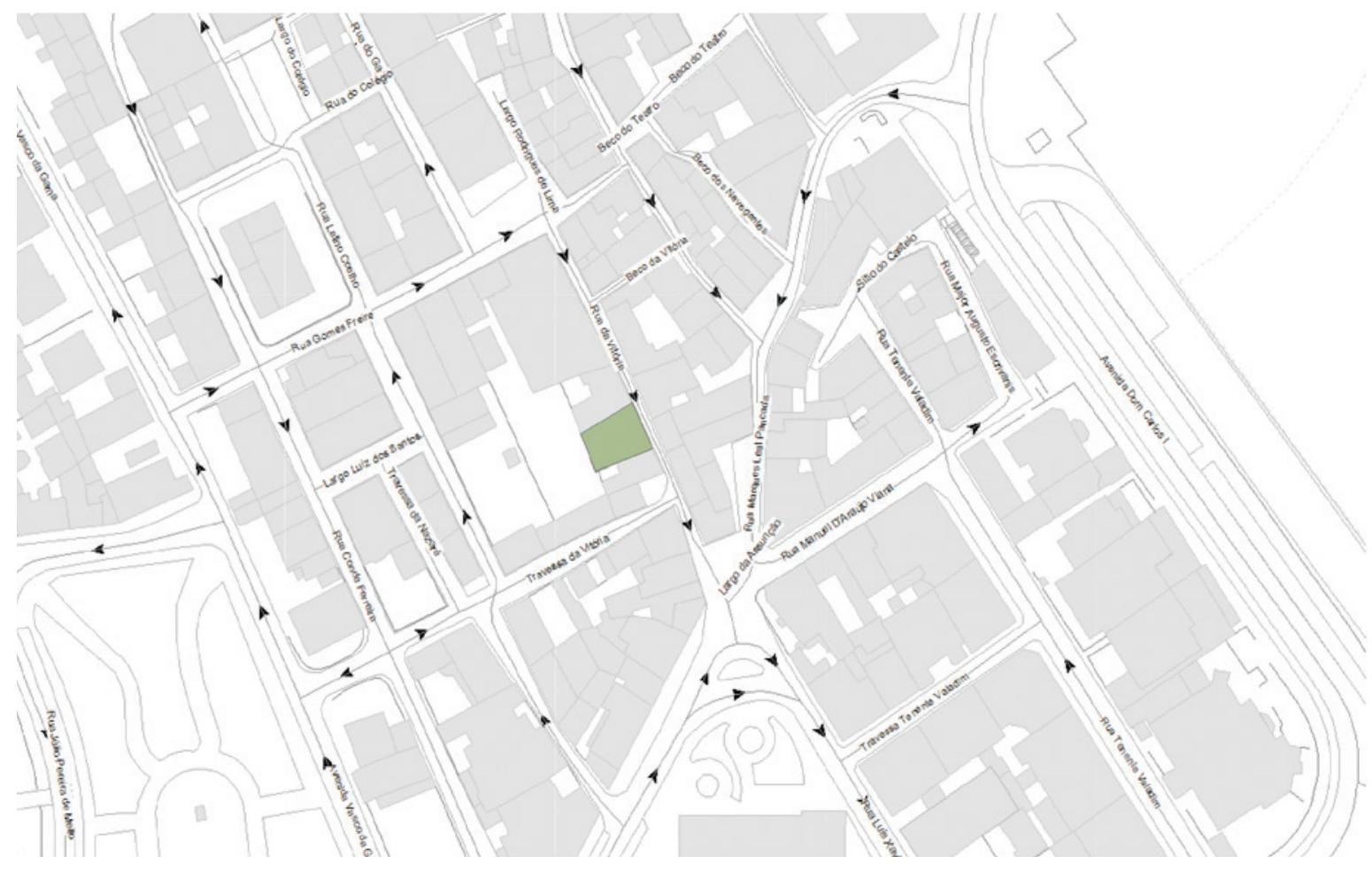

Figura 1 - Planta com localização do edifício (a verde) (Fonte: geocascais.cascais.pt).

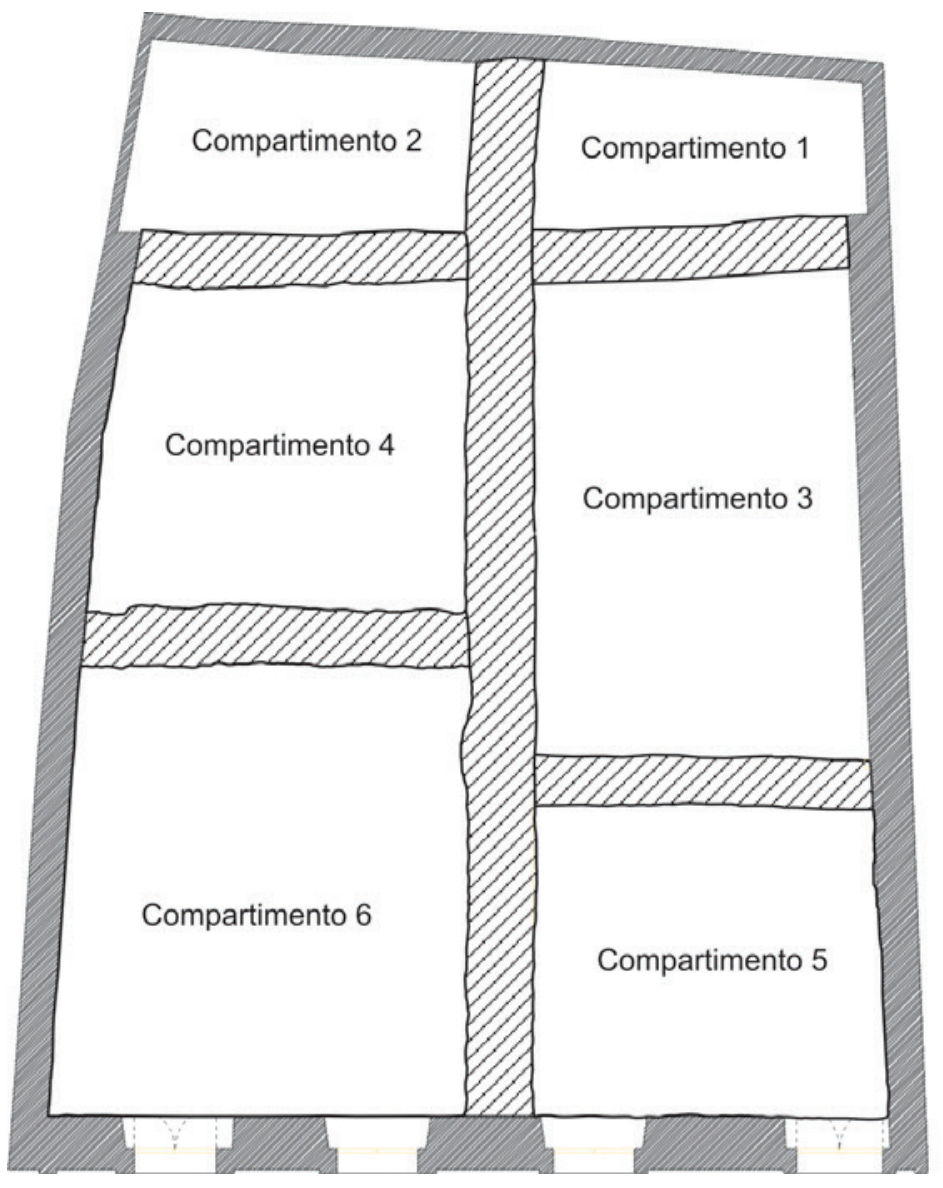

Figura 2 - Esquema dos compartimentos intervencionados. 


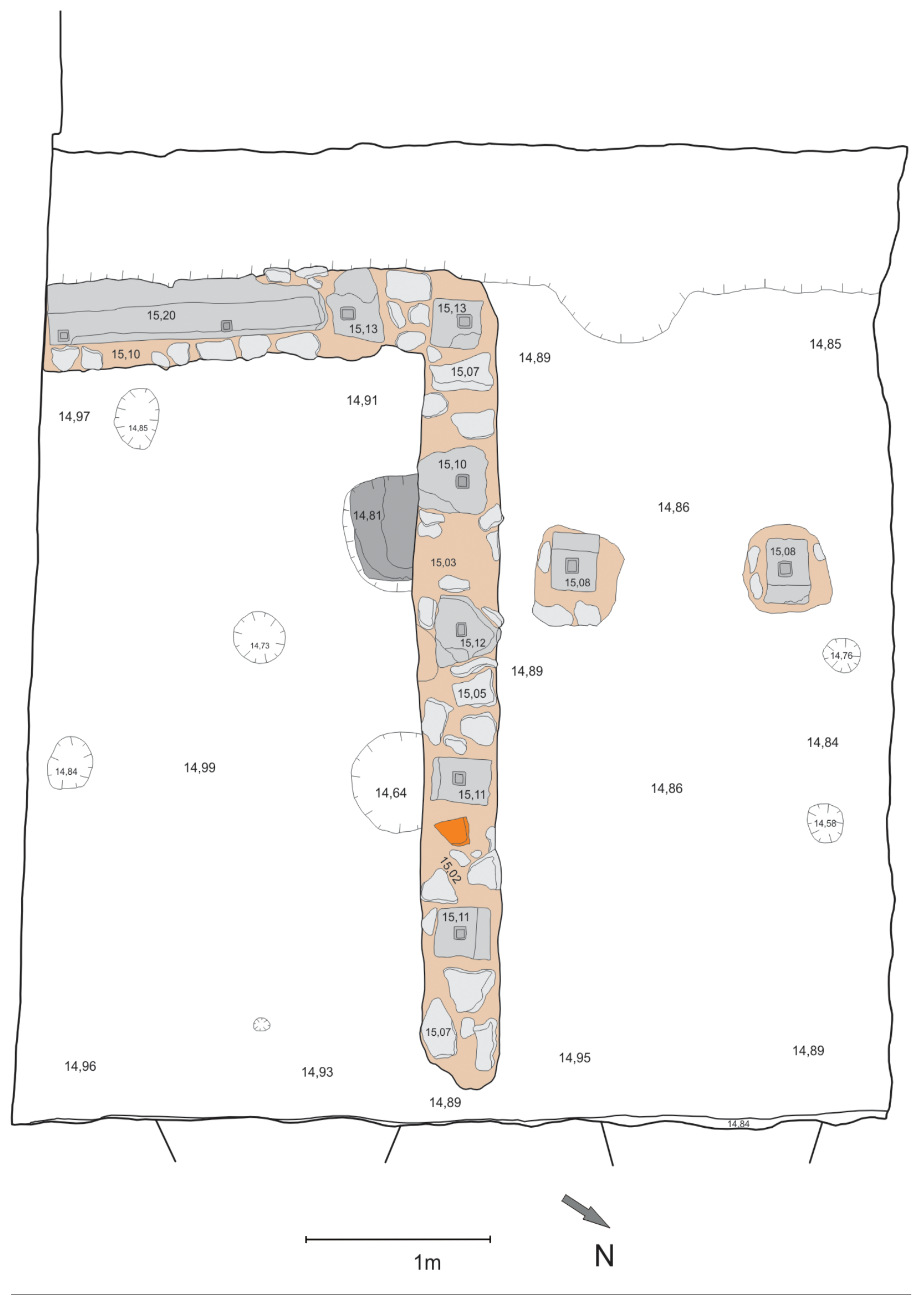

Figura 3-Estrutura de tabique identificado no compartimento 6. 


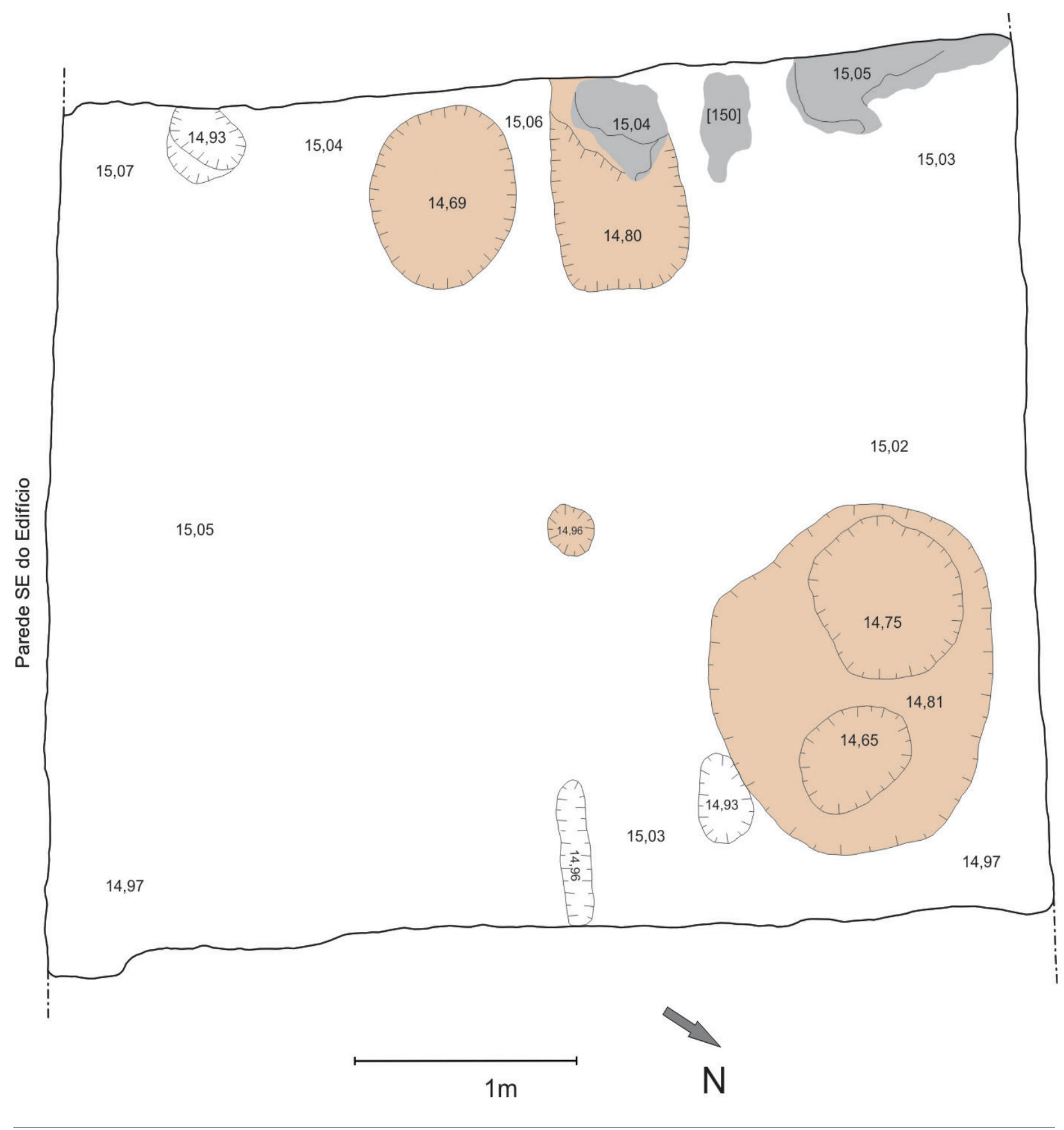

Figura 4 - Nível de fossas detríticas do compartimento 4 (a castanho claro). 


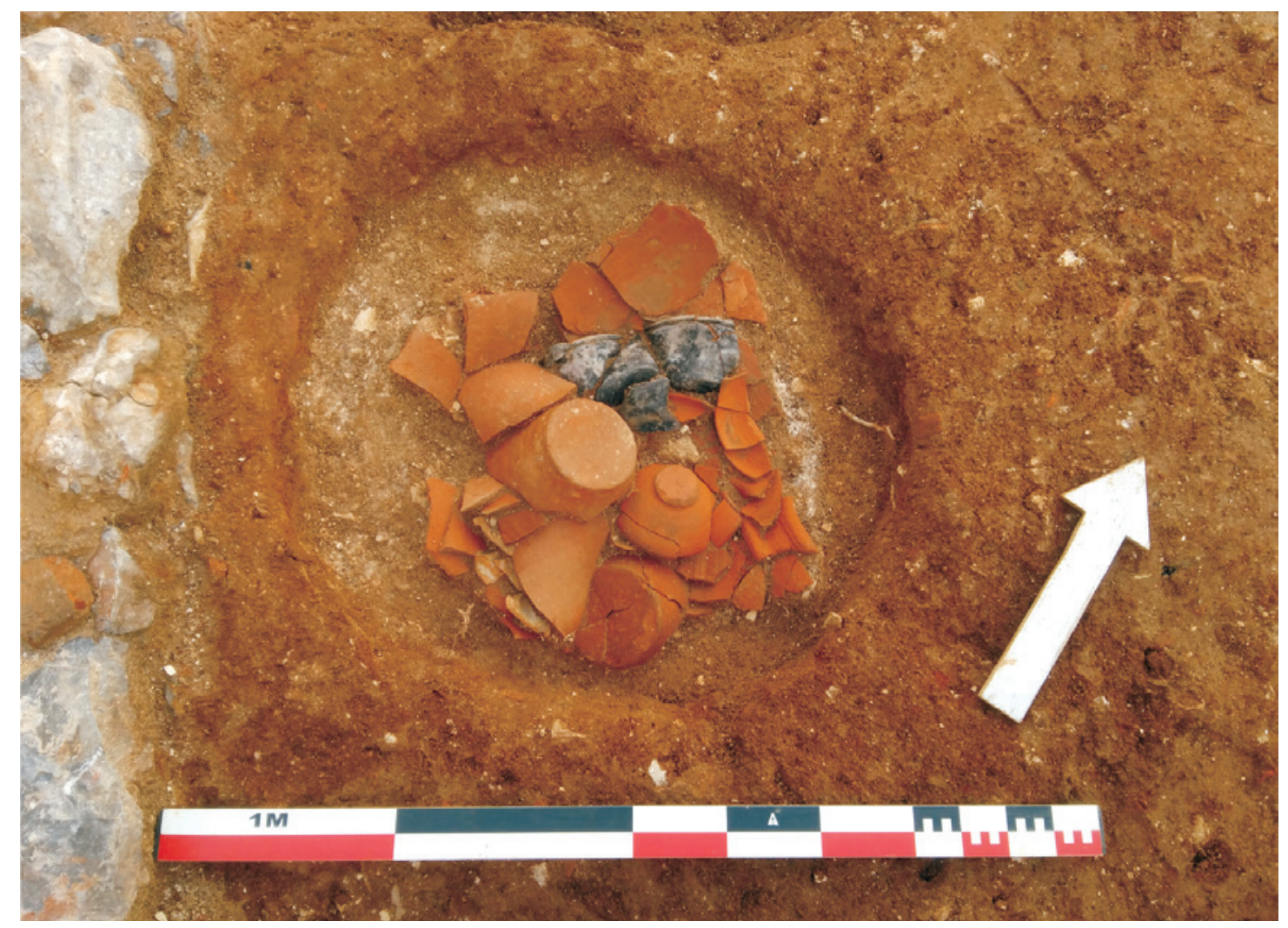

Figura 5- Pormenor da fossa detrítica identificada no compartimento 4.

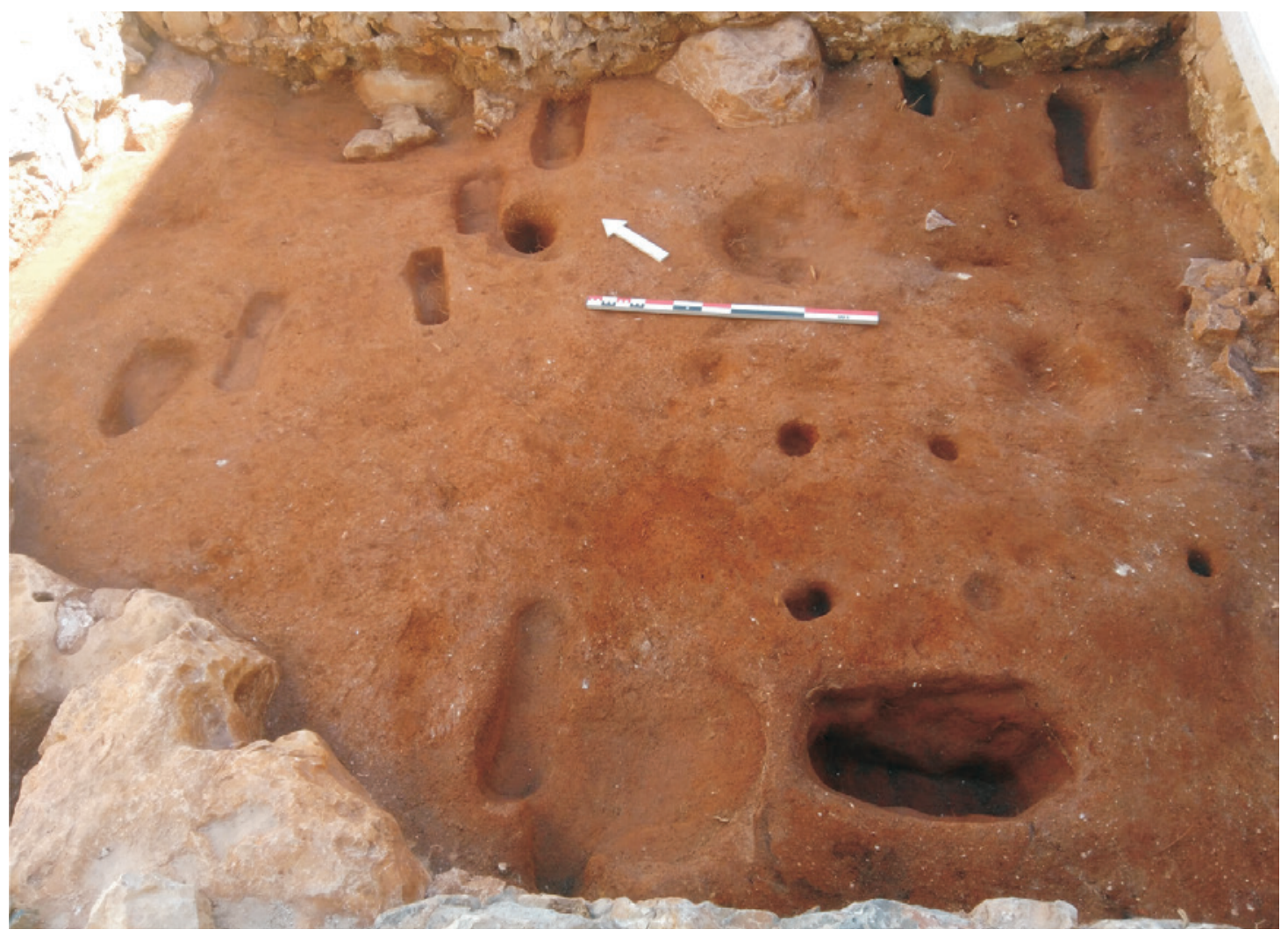

Figura 6 - Vista geral das estruturas negativas para pés de vinha do compartimento 4. 


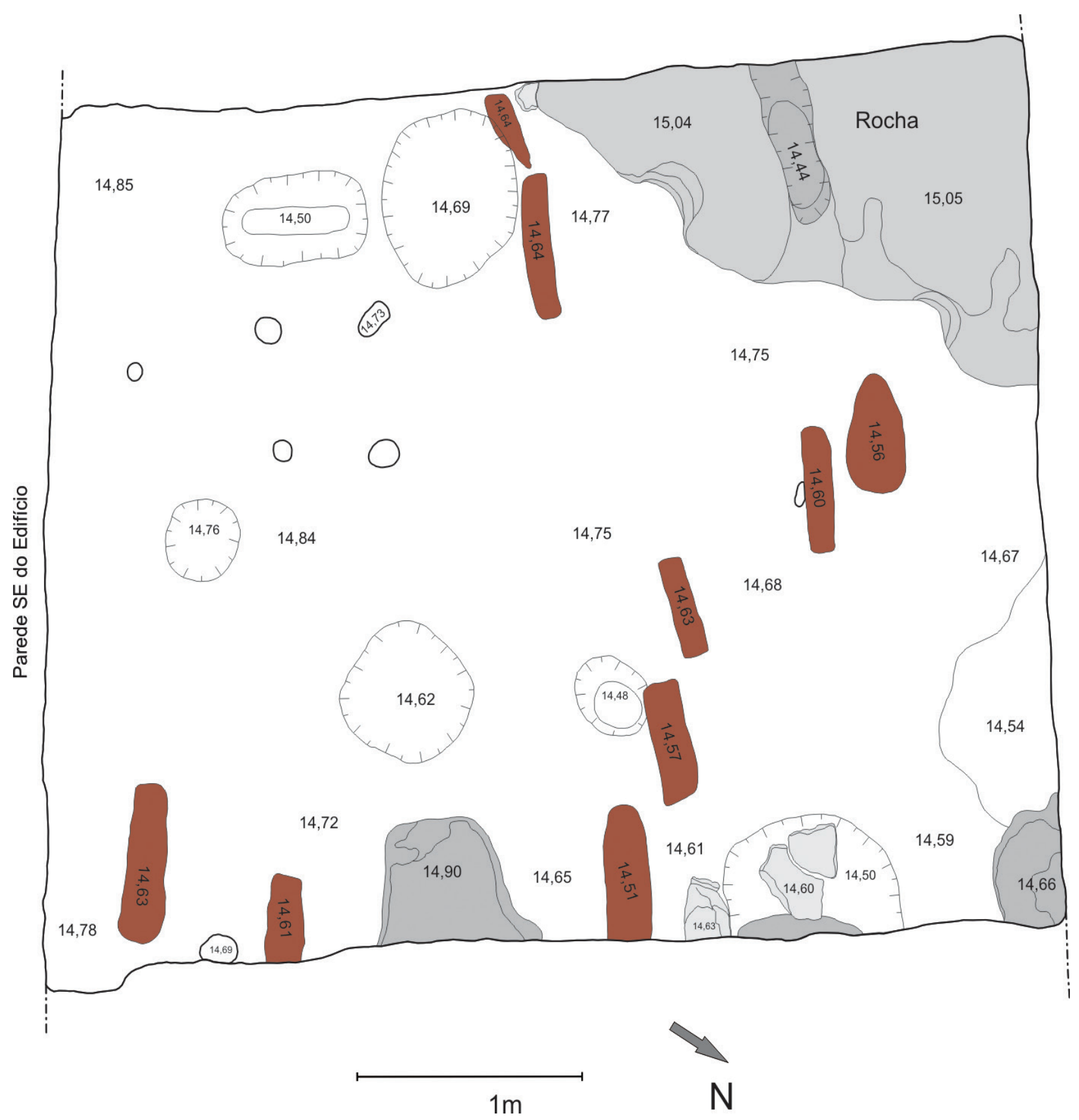

Figura 7 - Nível de ocupação agrícola com a implantação dos pés de vinha (a castanho). 


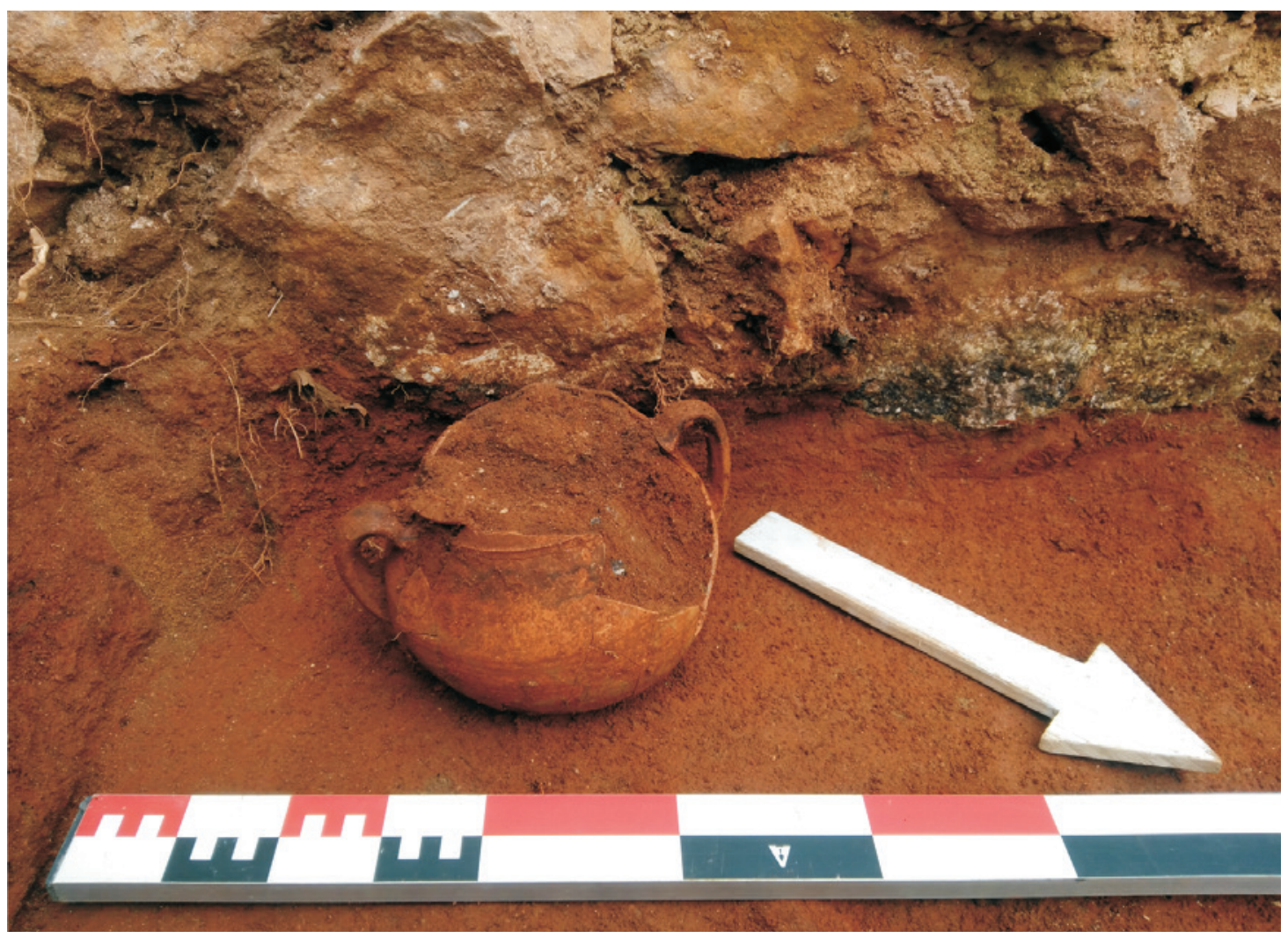

Figura 8 - Pormenor da panela in situ exumada no compartimento 4.

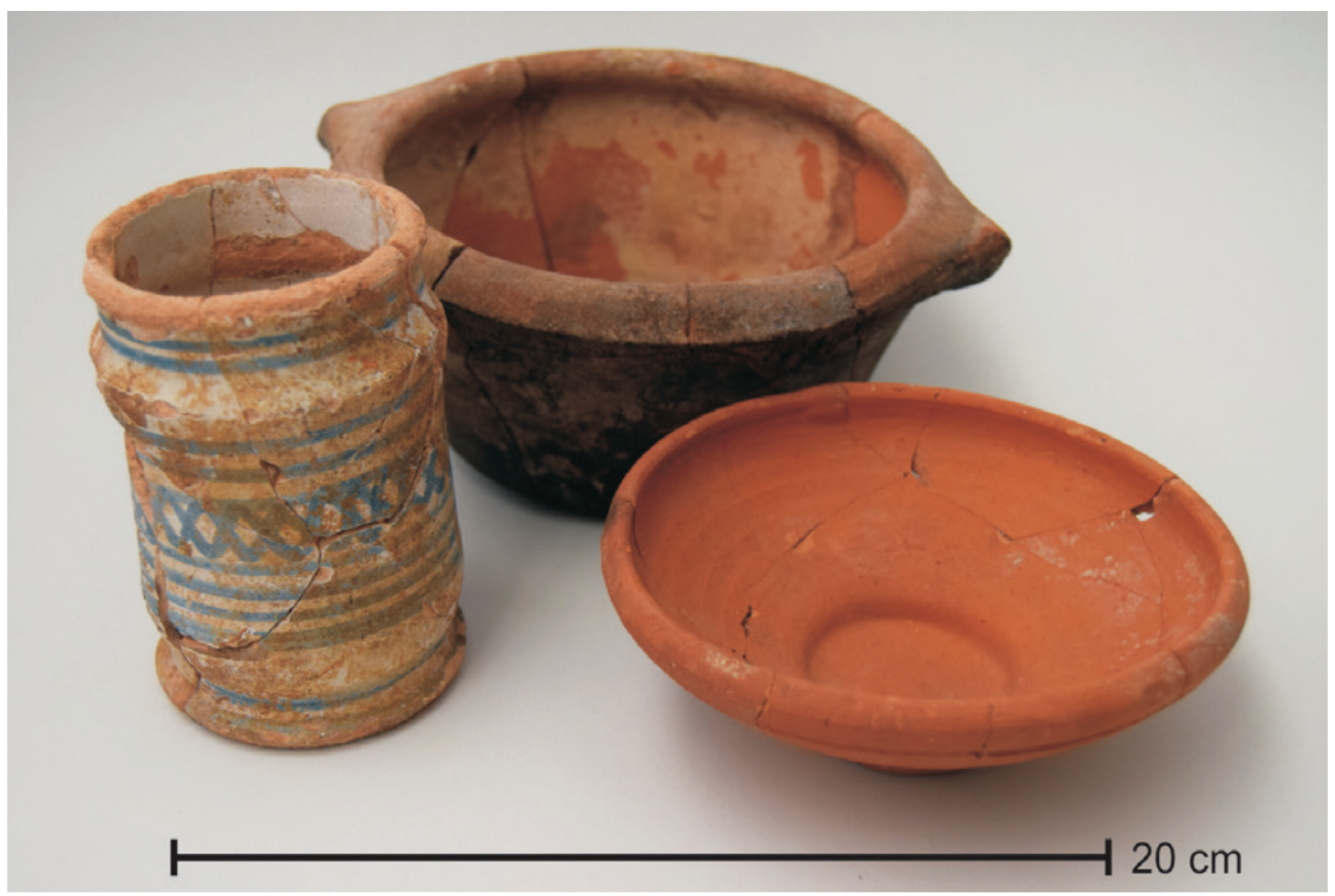

Figura 9-Materiais exumados na fossa do compartimento 4 (Autor: José Pedro Henriques). 


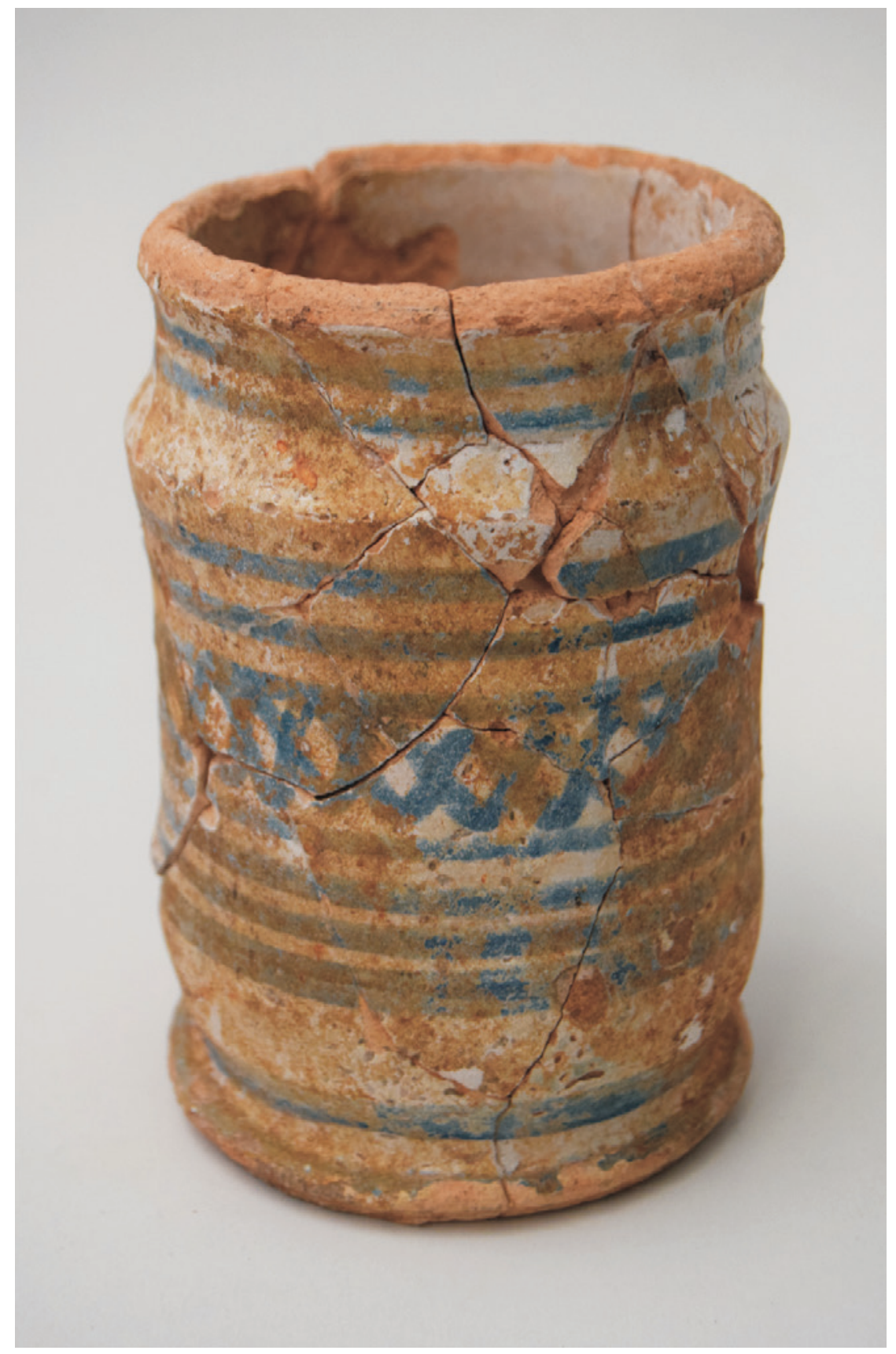

Figura 10 - Albarello de produção inglesa da segunda metade do século XVII (Autor: José Pedro Henriques). 



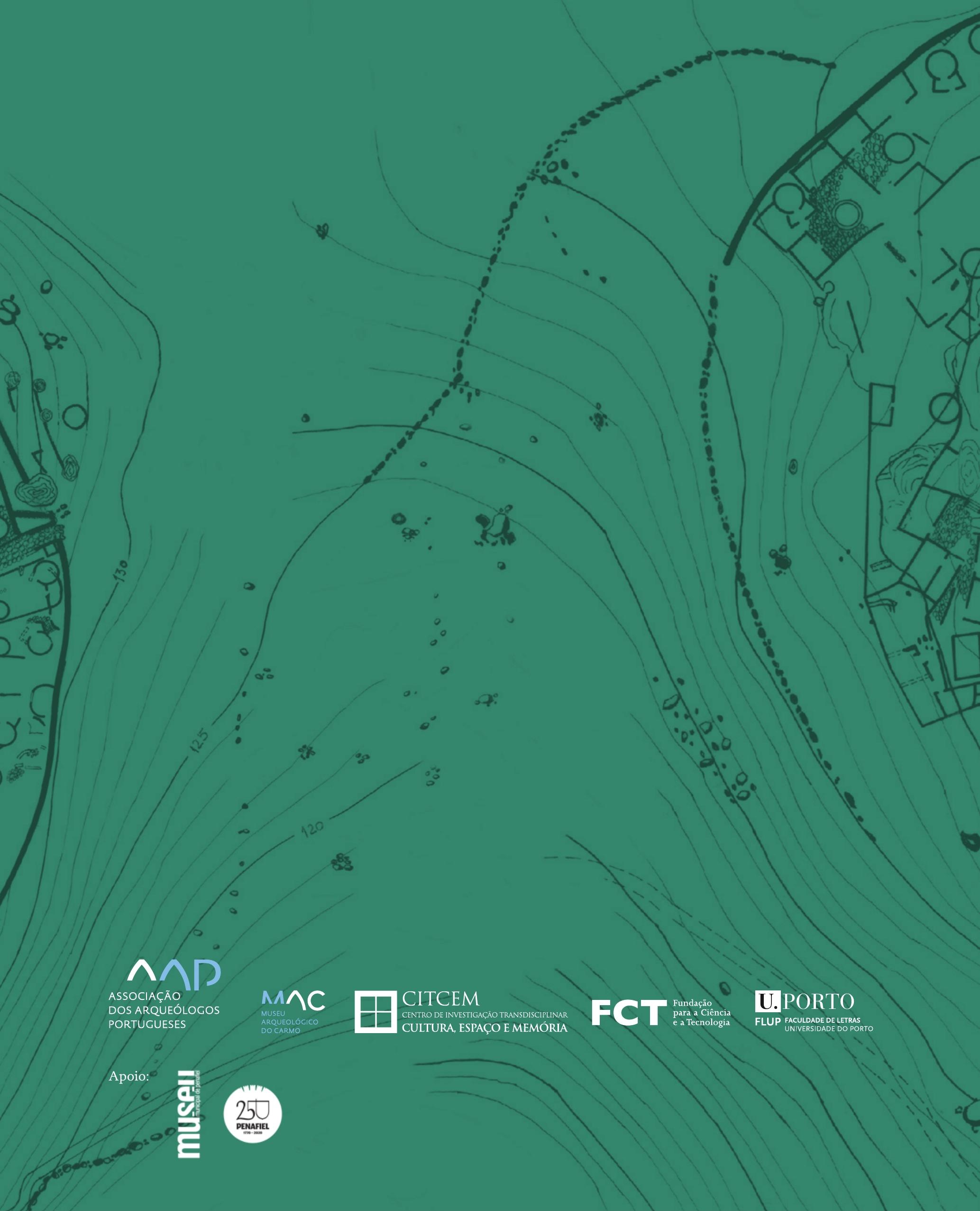

